Check for updates

Cite this: Mater. Adv., 2022, 3,2583

Received 15th December 2021, Accepted 1st February 2022

DOI: $10.1039 / \mathrm{d} 1 \mathrm{ma} 01181 \mathrm{~b}$

rsc.li/materials-advances

\title{
Aluminum sheet-induced porous zinc oxide nanosheets decorated with silver nanoparticles for ultrasensitive SERS sensing of crystal violet $\uparrow$
}

\author{
Xuejuan Chen, Qiuli Wang, Lixia Qin, * Xiaoxia Liu, Shi-Zhao Kang, (D) Taiyang Zhang \\ and Xiangqing $\mathrm{Li}$ (D) *
}

\begin{abstract}
In this work, porous zinc oxide $(\mathrm{ZnO})$ nanosheets induced by Al sheets were fabricated (Al/ZnO) via a simple hydrothermal method for the first time. Subsequently, various sizes of silver nanoparticles (AgNPs) were in situ decorated on $\mathrm{Al} / \mathrm{ZnO}$ and a highly sensitive surface enhancement Raman scattering (SERS) substrate Al/ZnO/Ag was prepared. The strong synergistic effect between AgNPs and Al/ZnO was confirmed by UV-vis diffuse reflectance and X-ray photoelectron spectroscopy (XPS). Interestingly, the substrate exhibited outstanding SERS response towards crystal violet (CV, a carcinogen used in external disinfectants) due to the high electromagnetic enhancement effect generated by AgNPs on the large amount of tip areas in $\mathrm{Al} / \mathrm{ZnO}$ as well as the charge transfer among the components. The results showed that $\mathrm{Al} / \mathrm{ZnO} / \mathrm{Ag}$ ( $\mathrm{Ag}$ content: $1.51 \mathrm{wt} \%$ ) can detect the SERS signal of CV molecules at a low concentration of $1 \times 10^{-13} \mathrm{~mol} \mathrm{~L}^{-1}$, and the analytical enhancement factors (AEF) can reach $2.45 \times 10^{8}$. In addition, the Raman activity of $\mathrm{Al} / \mathrm{ZnO} / \mathrm{Ag}$ hardly changed within 42 days or after seven cycles. Moreover, the $\mathrm{Al} / \mathrm{ZnO} / \mathrm{Ag}$ substrate displayed high sensitivity, good uniformity and repeatability for the SERS detection of CV, and it showed good selectivity towards CV in actual water samples. The results demonstrate that the low-cost and portable $\mathrm{Al} / \mathrm{ZnO} / \mathrm{Ag}$ substrate has excellent practical ability for the trace detection of CV.
\end{abstract}

\section{Introduction}

As a typical veterinary drug, crystal violet (CV) is often used as a fungicide and antiparasitic drug in fish farming around the world. ${ }^{1,2}$ However, it is highly teratogenic, toxic and carcinogenic, which has a serious impact on the food chain, the ecosystem and human health. Therefore, it is vital to establish a sensitive and rapid method for the determination of $\mathrm{CV}$ in fishing waters.

Surface enhancement Raman scattering (SERS) is a highly sensitive and effective analytical technology that can quickly identify various molecules. ${ }^{3,4}$ It is well known that $\mathrm{Au}$ or $\mathrm{Ag}$ have been constructed as nanostructures for SERS detection due to their stronger localized surface plasmon resonance (LSPR) characteristics. ${ }^{5-8}$ Specifically, the appropriate size of AgNPs can provide a higher SERS enhancement effect. ${ }^{9,10}$ However, the disadvantages of noble metal Ag substrates, such

School of Chemical and Environmental Engineering, Center of Graphene Research, Shanghai Institute of Technology, 100 Haiquan Road, Shanghai 201418, China. E-mail:xqli@sit.edu.cn, lxqin@sit.edu.cn; Fax: +86 21 64253317; Tel: +862160873061

$\dagger$ Electronic supplementary information (ESI) available. See DOI: 10.1039/d1ma01181b as high cost, poor stability and non-recyclability, limit their practical application.

Among the semiconductor SERS substrates, ZnO has been proven to be a promising candidate because of its structural versatility, tunable optical properties, efficient charge/energytransfer processes with molecular structures, and so on. ${ }^{11-16}$ More importantly, by combining noble metal NPs with pure semiconductors, the LSPR absorption region of composite substrates can be expanded, which improves their SERS activity. ${ }^{17-19}$ Recently, a few Ag/ZnO-based nanocomposites have been constructed for SERS detection. For instance, three-dimensional ordered $\mathrm{Ag} / \mathrm{ZnO} / \mathrm{Si}$ hierarchical nanoflower arrays were fabricated, which showed an ultrasensitive detection limit for Rhodamine $6 \mathrm{G}$ (R6G) as low as $1 \times$ $10^{-12} \mathrm{~mol} \mathrm{~L}^{-1} .^{20} \mathrm{Ag}$-coated flower-like $\mathrm{ZnO}$ nanorods arrays were prepared for the highly sensitive SERS detection of R6G at a low concentration of $1 \times 10^{-14} \mathrm{~mol} \mathrm{~L}^{-1} \cdot{ }^{21} \mathrm{ZnO}$ nanosheets have proven to be effective in promoting SERS activity as their tip effects can provide more hot spots for AgNPs, which greatly enhances the electromagnetic (EM) enhancement effect of the $\mathrm{ZnO}$ nanosheet/Ag system. ${ }^{22,23}$ For example, $\mathrm{ZnO}-\mathrm{Ag}$ hybrid mesoporous nanosheets grafted on ordered $\mathrm{Si}$ micropillar arrays were constructed for the sensitive SERS detection of 
explosives. ${ }^{24}$ Also, the 3D flexible substrate was designed via seeded $\mathrm{ZnO}$ nanosheets on aluminum foil by sputtering a layer of $\mathrm{Au}$ and deposited AgNPs, and numerous hot spots were established by $\mathrm{Au}$ and AgNPs on the substrate, which can be used for the sensitive detection of fungicide thiram $\left(0.2 \mathrm{ng} \mathrm{cm}{ }^{-2}\right) .{ }^{25}$ However, the preparation method of the above substrates is relatively complex and costly, and also the detection sensitivity for environmental pollutants needs to be further improved. Therefore, the construction of ZnO nanosheets/Ag system with low cost, high sensitivity, and good recyclability is expected to be used for the SERS detection of trace CV in real environmental water samples.

In this work, aluminum ( $\mathrm{Al})$ sheet-induced porous $\mathrm{ZnO}$ nanosheets $(\mathrm{Al} / \mathrm{ZnO})$ with dense lamellar stack structure were prepared by a simple hydrothermal method. Subsequently, Al/ $\mathrm{ZnO}$ decorated with different sizes of AgNPs (Al/ZnO/Ag) were constructed by the in situ reduction method. Interestingly, a strong electric field coupling effect was generated when AgNPs were loaded on large amounts of tip areas of $\mathrm{ZnO}$ in $\mathrm{Al} / \mathrm{ZnO}$. The relationship between the size of AgNPs and the SERS performance of $\mathrm{CV}$ on the $\mathrm{Al} / \mathrm{ZnO} / \mathrm{Ag}$ substrate was investigated in detail. In addition, the stability, uniformity, reproducibility, and selectivity of $\mathrm{CV}$ on the $\mathrm{Al} / \mathrm{ZnO} / \mathrm{Ag}$ substrate were further investigated.

\section{Experimental section}

\subsection{Reagents}

Al sheet (95\% huaxin metal), sodium hydroxide ( $\mathrm{NaOH}, 96 \%)$, hexamine $\left(\mathrm{C}_{6} \mathrm{H}_{12} \mathrm{~N}_{4}, 99.99 \%\right)$, zinc nitrate hexahydrate $\left(\mathrm{Zn}\left(\mathrm{NO}_{3}\right)_{2} \cdot 6 \mathrm{H}_{2} \mathrm{O}, 99.99 \%\right)$, silver nitrate $\left(\mathrm{AgNO}_{3}, \mathrm{AR}\right)$, ascorbic acid $\left(\mathrm{C}_{6} \mathrm{H}_{8} \mathrm{O}_{6}, \mathrm{AR}\right)$, acetone $\left(\mathrm{C}_{3} \mathrm{H}_{6} \mathrm{O}, \mathrm{AR}\right)$, and ethanol $\left(\mathrm{C}_{2} \mathrm{H}_{5} \mathrm{OH}\right.$, $\mathrm{AR})$ were purchased from Sinopharm group chemical reagent Co. Ltd.

\subsection{Assembly of $\mathrm{Al} / \mathrm{ZnO} / \mathrm{Ag}$ substrates}

Firstly, Al was sliced into $2 \mathrm{~cm} \times 4 \mathrm{~cm}$ sheets, the stains on the surface were removed with detergent, etched in $\mathrm{NaOH}$ solution $\left(0.5 \mathrm{~mol} \mathrm{~L}^{-1}\right)$ for $5 \mathrm{~min}$, and then washed three times with distilled water. Secondly, the etched Al sheets were soaked in a solution of $\mathrm{Zn}\left(\mathrm{NO}_{3}\right)_{2} \cdot 6 \mathrm{H}_{2} \mathrm{O}\left(0.5 \mathrm{~mol} \mathrm{~L}{ }^{-1}\right)$ and $\mathrm{C}_{6} \mathrm{H}_{12} \mathrm{~N}_{4}$ $\left(0.5 \mathrm{~mol} \mathrm{~L}^{-1}\right)$ with a molar ratio of $1: 1$ in a water bath and reacted at $88{ }^{\circ} \mathrm{C}$ for $3 \mathrm{~h}$. The $\mathrm{Al} / \mathrm{ZnO}$ substrate was obtained by washing with distilled water and blow-drying. Thirdly, Al/ZnO was immersed in $30 \mathrm{~mL} \mathrm{AgNO}_{3}$ solution $\left(0.05 \mathrm{~mol} \mathrm{~L}^{-1}\right)$ for $10 \mathrm{~min}$. Under vigorous stirring, a certain amount of ascorbic acid solution was slowly added to reduce $\mathrm{Ag}^{+}$. When the reduction time was $5 \mathrm{~min}$, the substrate was taken away, washed with distilled water, and air-dried. Using the same steps, $\mathrm{Al} / \mathrm{ZnO} / \mathrm{Ag}$ substrates with AgNPs of various sizes were prepared when the reduction time was $10 \mathrm{~min}, 15 \mathrm{~min}, 20 \mathrm{~min}$, $25 \mathrm{~min}$, and $30 \mathrm{~min}$, respectively. For comparison, in the absence of $\mathrm{ZnO}, \mathrm{Al} / \mathrm{Ag}$ was also prepared according to the above method. Moreover, the $\mathrm{ZnO}$ and $\mathrm{ZnO} / \mathrm{Ag}$ samples for TEM images were prepared by scraping off the surface of the $\mathrm{Al} / \mathrm{ZnO} / \mathrm{Ag}$ substrate.

\subsection{Raman spectra measurement}

$20 \mu \mathrm{L}$ of $1 \times 10^{-7} \mathrm{~mol} \mathrm{~L}^{-1} \mathrm{CV}$ solution was dropped onto the surface of the $\mathrm{Al} / \mathrm{ZnO} / \mathrm{Ag}$ sheet $(2 \mathrm{~cm} \times 4 \mathrm{~cm})$ with a radius of $0.5 \mathrm{~cm}$, and the Raman spectra of CV from multiple spots were collected by Raman spectroscopy (acquisition time: $20 \mathrm{~s}$, excitation wavelength: $532 \mathrm{~nm}$, and Raman laser spot radius: $2 \mathrm{~mm}$ ). In addition, Raman signals of $1 \times 10^{-7} \mathrm{~mol} \mathrm{~L}^{-1} \mathrm{CV}$ on $\mathrm{Al}, \mathrm{Al} /$ $\mathrm{ZnO}, \mathrm{ZnO} / \mathrm{Ag}$, and $\mathrm{Al} / \mathrm{Ag}$ substrates were also measured under the same conditions, respectively.

The SERS measurement procedures of different concentrations were as follows: CV solutions of different concentrations $\left(1 \times 10^{-13} \mathrm{~mol} \mathrm{~L}^{-1}-1 \times 10^{-7} \mathrm{~mol} \mathrm{~L}^{-1}\right)$ were consecutively dropped onto the same batch of $\mathrm{Al} / \mathrm{ZnO} / \mathrm{Ag}$ substrates, and multiple points were selected on different substrates for the acquisition of Raman spectra. Moreover, the analytical enhancement factor (AEF) was calculated by the Raman intensity ratio of $1 \times 10^{-7} \mathrm{~mol} \mathrm{~L}{ }^{-1} \mathrm{CV}$ on the $\mathrm{Al} / \mathrm{ZnO} / \mathrm{Ag}$ substrate to the $1 \times 10^{-3} \mathrm{~mol} \mathrm{~L}^{-1} \mathrm{CV}$ on the $\mathrm{Al}$ sheet.

2.4. The stability, uniformity, and repeatability of the $\mathrm{Al} / \mathrm{ZnO} /$ Ag substrate

$1 \times 10^{-7} \mathrm{~mol} \mathrm{~L}^{-1} \mathrm{CV}$ solution was dropped onto the $\mathrm{Al} / \mathrm{ZnO} / \mathrm{Ag}$ substrate and then was kept for 42 days. The stability of the $\mathrm{Al} /$ $\mathrm{ZnO} / \mathrm{Ag}$ substrate was investigated by measuring the Raman signals of $\mathrm{CV}$ at different time periods. In addition, the newly prepared $1 \times 10^{-7} \mathrm{~mol} \mathrm{~L}^{-1} \mathrm{CV}$ solution was added into the $\mathrm{Al} /$ $\mathrm{ZnO} / \mathrm{Ag}$ surface, and SERS signals of thirty-six different points on the substrate were collected to study the uniformity of the $\mathrm{Al} / \mathrm{ZnO} / \mathrm{Ag}$ substrate. After the Raman signal was collected in situ, the substrate was immersed in distilled water for $12 \mathrm{~h}$ and then dried. Then, CV solution $\left(1 \times 10^{-7} \mathrm{~mol} \mathrm{~L}^{-1}\right)$ was dropped onto the substrate surface again, and the SERS signal was measured in situ. Next, the Raman signals of CV were collected seven times repeatedly to study the reproducibility of the $\mathrm{Al} / \mathrm{ZnO} / \mathrm{Ag}$ substrate.

\subsection{The selectivity of the $\mathrm{Al} / \mathrm{ZnO} / \mathrm{Ag}$ substrate for the SERS detection of $\mathrm{CV}$}

4-Thiophenol aminophenol (4-ATP), methylene blue (MB), thioglycolic acid (TA), malachite green (MG), and CV with the same concentration of $1 \times 10^{-7} \mathrm{~mol} \mathrm{~L}^{-1}$ were added onto the surface of the $\mathrm{Al} / \mathrm{ZnO} / \mathrm{Ag}$ substrate for SERS detection, and all the SERS signals were collected, respectively. Also, in order to demonstrate the practical applicability of the substrate, the Raman spectrum of $1 \times 10^{-7} \mathrm{~mol} \mathrm{~L}^{-1} \mathrm{CV}$ spiked in real river water was measured.

\section{Results and discussion}

\subsection{Assembly process of the $\mathrm{Al} / \mathrm{ZnO} / \mathrm{Ag}$ substrates}

As shown in Scheme 1, firstly, the cleaned Al sheets $(2 \mathrm{~cm} \times$ $4 \mathrm{~cm}$ ) were etched in $\mathrm{NaOH}$ solution for $5 \mathrm{~min}$, and a large number of hydroxyl groups can be produced on $\mathrm{Al}$ sheets after the above process. Secondly, $\mathrm{Al}$ sheets were soaked in $\mathrm{Zn}\left(\mathrm{NO}_{3}\right)_{2}$. $6 \mathrm{H}_{2} \mathrm{O}$ and $\mathrm{C}_{6} \mathrm{H}_{12} \mathrm{~N}_{4}$ solution, and heated in a water-bath at $88{ }^{\circ} \mathrm{C}$ 


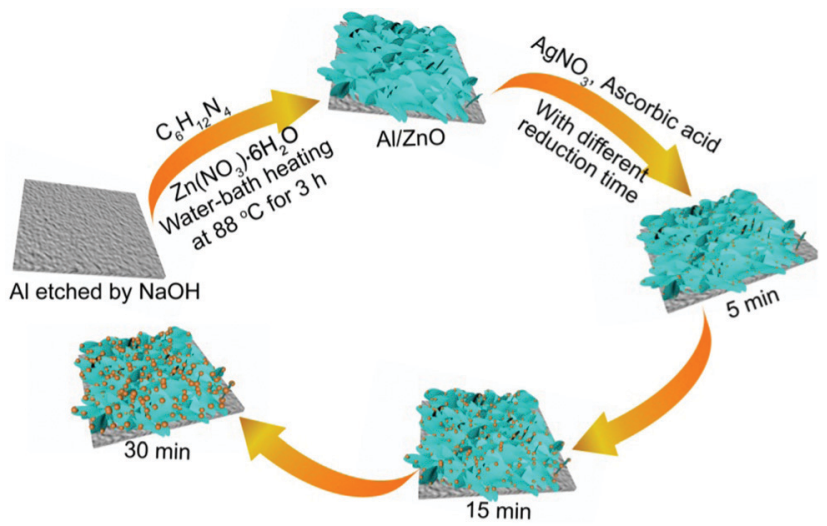

Scheme 1 Illustration of the preparation of the $\mathrm{Al} / \mathrm{ZnO} / \mathrm{Ag}$ substrate.

for $3 \mathrm{~h}$, and the $\mathrm{ZnO}$ nanosheets were obtained on the surface of the $\mathrm{Al}$ sheet. After that, the obtained $\mathrm{Al} / \mathrm{ZnO}$ was immersed in $\mathrm{AgNO}_{3}$ solution with the concentration of $0.05 \mathrm{~mol} \mathrm{~L}^{-1}$, and $\mathrm{Ag}^{+}$ was gradually reduced to AgNPs following the addition of ascorbic acid. By changing the reduction time, $\mathrm{Al} / \mathrm{ZnO} / \mathrm{Ag}$ substrates with the loading of various sizes of AgNPs were obtained.

\subsection{Morphological characterization of $\mathrm{Al} / \mathrm{ZnO}$ and $\mathrm{ZnO}$}

As shown in Fig. 1, the morphology of $\mathrm{Al} / \mathrm{ZnO}$ and $\mathrm{ZnO}$ was characterized by the SEM and TEM images. As illustrated in Fig. 1A, obviously, the SEM image of $\mathrm{Al} / \mathrm{ZnO}$ indicates that $\mathrm{ZnO}$ has a ridged lamellar structure on the $\mathrm{Al}$ sheet. Also, the surface layer of $\mathrm{ZnO}$ presents a dense porous structure on the $\mathrm{Al}$ sheet (Fig. 1C), and the pores are mainly focused at $\sim 3 \mathrm{~nm}$ and in the range of 12-35 $\mathrm{nm}$ (Fig. S1, ESI $\dagger$ ). However, in the SEM (Fig. 1B) and TEM (Fig. 1D) images of $\mathrm{ZnO}$ without the induction of $\mathrm{Al}$, it is evident that $\mathrm{ZnO}$ shows a shuttle-like structure with a smooth surface. Therefore, the Al sheet can be used as an excellent template to facilitate the formation of $\mathrm{ZnO}$ with a stacked lamellar structure, which would supply several active sites for the loading of AgNPs, and also its dense porous structure could adsorb more target molecules.

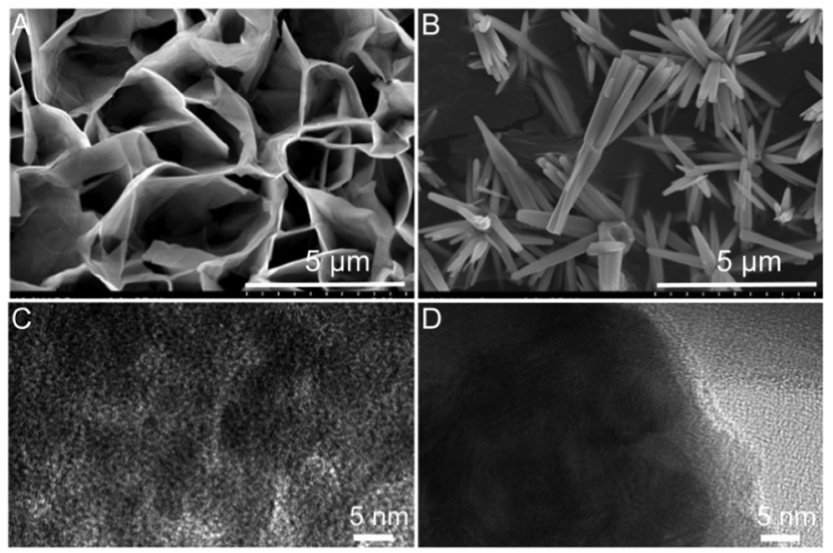

Fig. 1 SEM images of (A) $\mathrm{Al} / \mathrm{ZnO}$ and (B) $\mathrm{ZnO}$; high-resolution TEM images of (C) $\mathrm{Al} / \mathrm{ZnO}$ and (D) $\mathrm{ZnO}$.

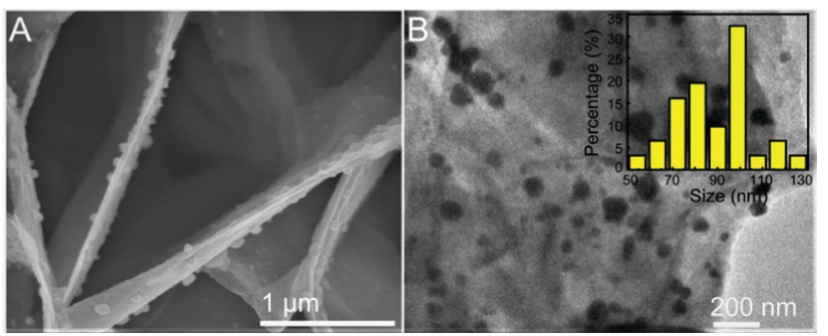

Fig. 2 (A) SEM and (B) TEM images of $\mathrm{Al} / \mathrm{ZnO} / \mathrm{Ag}$ at a reduction time of 15 min; the inset in $B$ is the corresponding size distribution of AgNPs in $\mathrm{Al} /$ $\mathrm{ZnO} / \mathrm{Ag}$

\subsection{Characterization of $\mathrm{Al} / \mathrm{ZnO} / \mathrm{Ag}$}

Fig. 2 show the SEM and TEM images of $\mathrm{Al} / \mathrm{ZnO} / \mathrm{Ag}$ and the corresponding size distribution of $\mathrm{AgNPs}$ in $\mathrm{Al} / \mathrm{ZnO} / \mathrm{Ag}$ at the reduction time of $15 \mathrm{~min}$. As illustrated in Fig. 2A, obviously, most AgNPs are spherical, which adhere closely to the surface of $\mathrm{Al} / \mathrm{ZnO}$ and mainly distribute on the tip regions and lamellas of ZnO. Additionally, the morphology and distribution state of $\mathrm{Ag}$ in $\mathrm{Al} / \mathrm{ZnO} / \mathrm{Ag}$ are characterized by the TEM image. As shown in Fig. 2B, it can be clearly observed that AgNPs exhibit uniform distribution on the surface of $\mathrm{ZnO}$, and the size is concentrated on $99 \mathrm{~nm}$. In addition, the SEM images of $\mathrm{Al} / \mathrm{ZnO} / \mathrm{Ag}$ with other reduction times of 5, 10, 20, and $30 \mathrm{~min}$ are also collected (Fig. S2, ESI $\dagger$ ). Briefly, when the reduction time was 5 or $10 \mathrm{~min}$, most of the AgNPs are irregular spheres (Fig. S2A and B, ESI $\dagger$ ). It can be observed from Fig. S2B and $\mathrm{C}$ (ESI $\dagger)$ that as the reduction time increases from $20 \mathrm{~min}$ to $30 \mathrm{~min}$, most AgNPs are aggregated significantly and the $\mathrm{Ag}$ nanoclusters are formed (Fig. S2D, ESI $\dagger$ ). The above results clearly reveal that the AgNPs have good dispersion and uniform size distribution when the reduction time is $15 \mathrm{~min}(\sim 99 \mathrm{~nm})$.

The possible explanations are as follows: firstly, the lamellar network structure of $\mathrm{ZnO}$ in the $\mathrm{Al} / \mathrm{ZnO}$ substrates have proper geometric restrains on the anisotropic growth of AgNPs. ${ }^{26,27}$ Secondly, the homogeneous porous structure on the edge and surface of $\mathrm{ZnO}$ nanosheets in $\mathrm{Al} / \mathrm{ZnO}$ provides more active sites for the growth of AgNPs. Therefore, the AgNPs are uniformly distributed on the lamellar edge and the homogeneous porous surface, and the size of AgNPs gradually increases until agglomeration is formed with the extension of the reduction time.

The morphology and phase of $\mathrm{Al} / \mathrm{ZnO}$ and $\mathrm{Al} / \mathrm{ZnO} / \mathrm{Ag}$ were further characterized by TEM and XRD. As shown in Fig. 3A and $\mathrm{B}$, clearly, the edges and surfaces of $\mathrm{ZnO}$ on the $\mathrm{Al}$ sheets have uniform porous structures, and the lattice spacings of $0.28 \mathrm{~nm}$ and $0.26 \mathrm{~nm}$ belonged to the crystal faces of $\mathrm{ZnO}(100)$ and (002), respectively. ${ }^{28}$ As illustrated in Fig. 3C and D, spherical AgNPs with uniform size can be observed on the surface of $\mathrm{Al}$ / $\mathrm{ZnO}$, and the lattice distances of $0.204 \mathrm{~nm}$ and $0.123 \mathrm{~nm}$ are assigned to the crystal planes of $\mathrm{Ag}(220)$ and (311), respectively. ${ }^{29}$ As shown in Fig. $3 \mathrm{E}, 2 \theta$ values at $22.7^{\circ}, 34.8^{\circ}$, and $61.4^{\circ}$ can be observed in $\mathrm{Al} / \mathrm{ZnO}$ (Fig. 3E-a) and $\mathrm{Al} / \mathrm{ZnO} / \mathrm{Ag}$ (Fig. 3E-b), which are ascribed to the crystal faces of $\mathrm{ZnO}(100)$, (002), and (103), respectively. ${ }^{30}$ Also, in the XRD pattern of $\mathrm{Al} /$ $\mathrm{ZnO} / \mathrm{Ag}$ (Fig. 3E-b), two peaks at $64.4^{\circ}$ and $77.3^{\circ}$ are obviously 

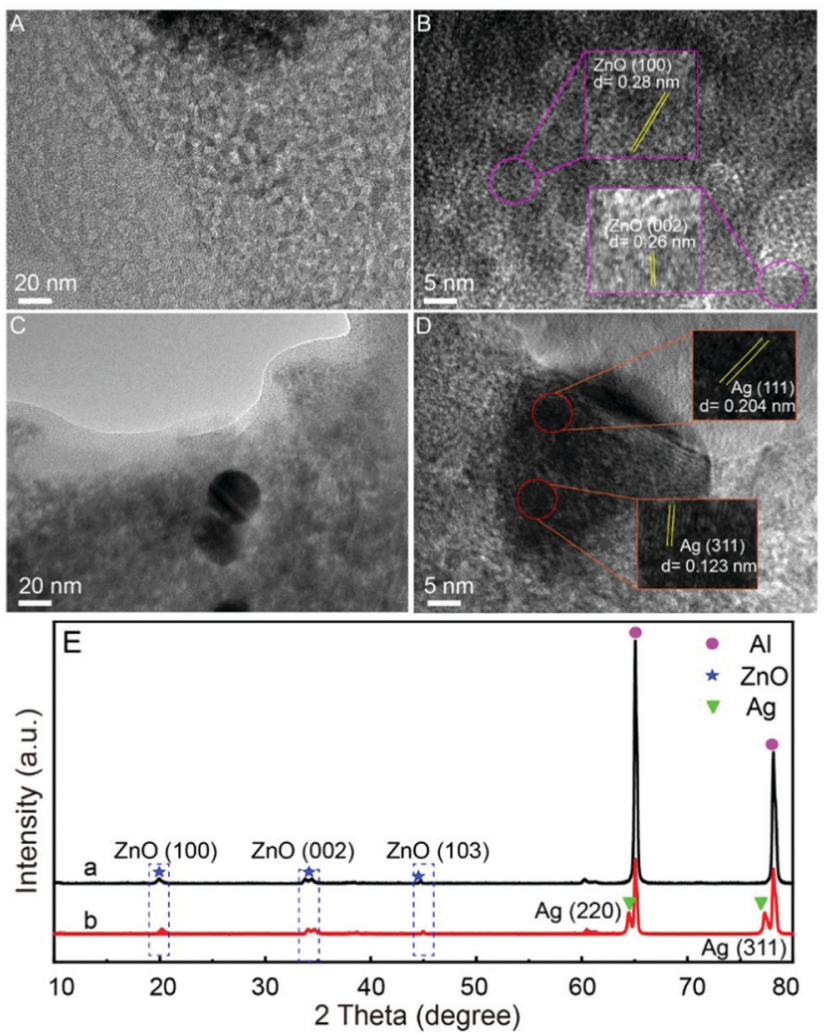

Fig. 3 TEM images of (A) $\mathrm{Al} / \mathrm{ZnO}$ and (C) Al/ZnO/Ag; HRTEM images of (B) $\mathrm{Al} / \mathrm{ZnO}$ and (D) Al/ZnO/Ag; (E) XRD patterns of $\mathrm{Al} / \mathrm{ZnO}$ (a) and $\mathrm{Al} / \mathrm{ZnO} /$ $\mathrm{Ag}(\mathrm{b})$.

observed, belonging to the (220) and (311) crystal faces of Ag, respectively, ${ }^{31}$ which are in good agreement with the TEM images. The above results indicate that the $\mathrm{Al} / \mathrm{ZnO} / \mathrm{Ag}$ substrate is successfully assembled.

Moreover, the distribution of various elements in $\mathrm{Al} / \mathrm{ZnO} / \mathrm{Ag}$ was measured by elemental mapping. As shown in Fig. S3B and $\mathrm{E},(\mathrm{ESI} \dagger)$ the main distribution of $\mathrm{Zn}$ presents a multilayer nanosheet structure, and the elemental $\mathrm{O}$ from $\mathrm{ZnO}$ is uniformly distributed in the sample (Fig. S3C, ESI $\dagger$ ). Also, the distribution of $\mathrm{Ag}$ element on the surface of $\mathrm{ZnO}$ lamellar array in $\mathrm{Al} / \mathrm{ZnO}$ is obviously observed (Fig. S3D, ESI $\dagger$ ). The overlay image of the elements shown in Fig. S3E (ESI $\dagger$ ) corresponds to the SEM image of $\mathrm{Al} / \mathrm{ZnO} / \mathrm{Ag}$ (Fig. S3A, ESI $\dagger$ ). As illustrated in Fig. S4, (ESI $\dagger$ ) EDX analysis shows that the proportion of $\mathrm{Ag}$ is only $1.51 \mathrm{wt} \%$. These results further confirm that the $\mathrm{Al} / \mathrm{ZnO} / \mathrm{Ag}$ substrate with low cost is successfully fabricated.

The $\mathrm{Al} / \mathrm{ZnO}$ and $\mathrm{Al} / \mathrm{ZnO} / \mathrm{Ag}$ substrates were further characterized by XPS. In Fig. $4 \mathrm{~A}-\mathrm{a}$, the peaks of $\mathrm{Zn} 2 \mathrm{p}_{3 / 2}$ and $2 \mathrm{p}_{1 / 2}$ in $\mathrm{Al} /$ $\mathrm{ZnO}$ are situated at $1021.1 \mathrm{eV}$ and $1044.4 \mathrm{eV}$, respectively, ${ }^{32}$ which shift to $1021.8 \mathrm{eV}$ and $1044.9 \mathrm{eV}$ after the introduction of $\mathrm{Ag}$ in $\mathrm{Al} / \mathrm{ZnO}$ (Fig. 4A-b). The results demonstrated that there is strong binding ability between $\mathrm{ZnO}$ and Ag. From the XPS spectrum of $\mathrm{O} 1 \mathrm{~s}$ in $\mathrm{Al} / \mathrm{ZnO}$ (Fig. 4B-a), it can be found that the spectral lines are asymmetrical, which can be decomposed into two peaks, i.e., $531.4 \mathrm{eV}$ and $530.5 \mathrm{eV}$, respectively, indicating that there are two chemical states of $\mathrm{O}$ on the $\mathrm{Al} / \mathrm{ZnO}$
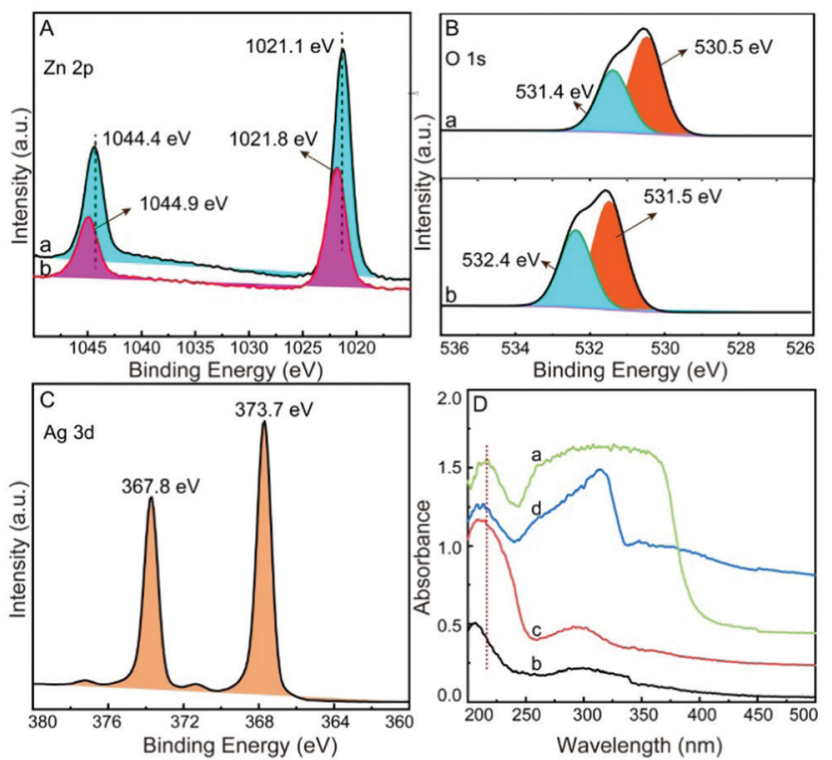

Fig. 4 High-resolution XPS of $\mathrm{Zn}(\mathrm{A}), \mathrm{O}(\mathrm{B})$ and $\mathrm{Ag}(\mathrm{C}), \mathrm{a}: \mathrm{Al} / \mathrm{ZnO}, \mathrm{b}: \mathrm{Al} /$ $\mathrm{ZnO} / \mathrm{Ag}$; (D) solid diffuse reflectance UV-vis absorption spectra of $\mathrm{ZnO}$ (a), $\mathrm{Al}(\mathrm{b}), \mathrm{Al} / \mathrm{ZnO}$ (c) and $\mathrm{Al} / \mathrm{ZnO} / \mathrm{Ag}(\mathrm{d})$.

surface. The peak at $531.4 \mathrm{eV}$ is related to the $\mathrm{O}$ lattice of the $\mathrm{ZnO}$ phase, and the peak at $530.5 \mathrm{eV}$ is relevant to the $\mathrm{O}$ binding hydroxide on the surface, which is perhaps due to the hydration or the defect sites of $\mathrm{ZnO} .{ }^{33,34}$ When the AgNPs are decorated on the $\mathrm{Al} / \mathrm{ZnO}$ surface, clearly, the peaks of $\mathrm{O} 1 \mathrm{~s}$ shift to $531.5 \mathrm{eV}$ and $532.4 \mathrm{eV}$ (Fig. 4B-b), respectively, demonstrating that strong coupling occurs between AgNPs and $\mathrm{ZnO}$ in $\mathrm{Al} / \mathrm{ZnO}{ }^{35}$ As illustrated in Fig. 4C, the peaks at $373.7 \mathrm{eV}$ and $367.8 \mathrm{eV}$ are attributed to $\mathrm{Ag} 3 \mathrm{~d}_{3 / 2}$ and $3 \mathrm{~d}_{5 / 2}$, respectively. The difference between the binding energies of $\mathrm{Ag} 3 \mathrm{~d}_{3 / 2}$ and $3 \mathrm{~d}_{5 / 2}$ is about $6.0 \mathrm{eV}$, which further proves that metal $\mathrm{Ag}$ exists in $\mathrm{Al} /$ $\mathrm{ZnO} / \mathrm{Ag}^{36}$

Solid diffuse reflectance UV-vis absorption spectra of $\mathrm{ZnO}$ (a), $\mathrm{Al}$ (b), $\mathrm{Al} / \mathrm{ZnO}$ (c), and $\mathrm{Al} / \mathrm{ZnO} / \mathrm{Ag}$ (d) are measured. As illustrated in Fig. 4D-a, an absorption peak at $216 \mathrm{~nm}$ and the obvious UV-light absorption in the range of $250 \mathrm{~nm}-400 \mathrm{~nm}$ are clearly observed in the spectrum of $\mathrm{ZnO} .{ }^{37}$ In comparison of $\mathrm{ZnO}$ (Fig. 4D-a) and $\mathrm{Al}$ sheet (Fig. 4D-b), the characteristic peak of $\mathrm{ZnO}$ in $\mathrm{Al} / \mathrm{ZnO}$ shifts from 216 to $209 \mathrm{~nm}$ (Fig. 4D-c), indicating that there is strong coupling between the etched $\mathrm{Al}$ sheet and $\mathrm{ZnO}$. Also, in the spectrum of $\mathrm{Al} / \mathrm{ZnO} / \mathrm{Ag}$ (Fig. 4D-d), an absorption peak at $400 \mathrm{~nm}$ corresponding to the plasma absorption of $\mathrm{Ag}$ is clearly observed, ${ }^{38}$ and the typical peak of $\mathrm{ZnO}$ in the $\mathrm{Al} / \mathrm{ZnO} / \mathrm{Ag}$ is shifted to $213 \mathrm{~nm}$, demonstrating that there exists strong binding ability between $\mathrm{Ag}$ and $\mathrm{ZnO}$ in $\mathrm{Al} /$ ZnO. By means of SEM, TEM, XRD, XPS, and UV-vis absorption, it is confirmed that $\mathrm{Al} / \mathrm{ZnO} / \mathrm{Ag}$ is successfully fabricated by strong coupling among $\mathrm{Al}, \mathrm{ZnO}$, and $\mathrm{Ag}$.

\subsection{Raman response of different substrates with various reduction times}

Moreover, with CV as a target molecule (its structure was shown in Fig. S5, ESI $\dagger$ ), the SERS activity of the $\mathrm{Al} / \mathrm{ZnO} / \mathrm{Ag}$ substrates 

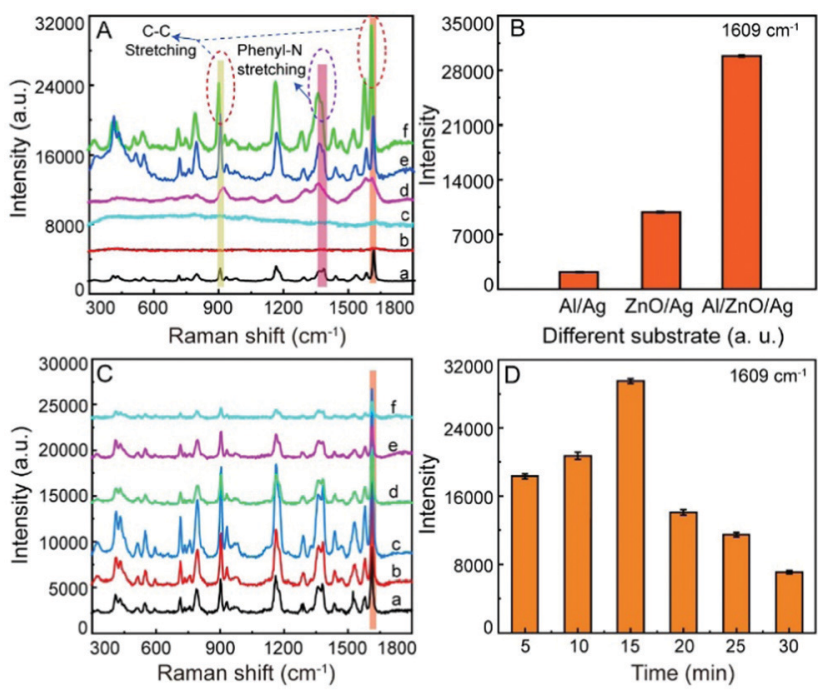

Fig. 5 (A) SERS response of $1 \times 10^{-3} \mathrm{~mol} \mathrm{~L}^{-1} \mathrm{CV}$ on Al sheet (a) and SERS response of $1 \times 10^{-7} \mathrm{~mol} \mathrm{~L}-1 \mathrm{CV}$ on $\mathrm{Al}$ (b), $\mathrm{Al} / \mathrm{ZnO}$ (c), $\mathrm{Al} / \mathrm{Ag}$ (d), $\mathrm{ZnO} / \mathrm{Ag}(\mathrm{e})$, and $\mathrm{Al} / \mathrm{ZnO} / \mathrm{Ag}(\mathrm{f})$, and $(\mathrm{B})$ the corresponding histogram for the SERS intensity based on the typical band at $1609 \mathrm{~cm}^{-1}$. (C) Raman response of $1 \times 10^{-7} \mathrm{~mol} \mathrm{~L}{ }^{-1} \mathrm{CV}$ on $\mathrm{Al} / \mathrm{ZnO} / \mathrm{Ag}$ with different reduction times (a-f: 5 , $10,15,20,25$, and $30 \mathrm{~min}$ ) and (D) the corresponding histogram for the SERS intensity at the characteristic band of $1609 \mathrm{~cm}^{-1}$. The error bar is the standard deviation calculated from three samples.

was evaluated. As illustrated in Fig. 5A-a, clearly, the typical Raman peaks of $1 \times 10^{-3} \mathrm{~mol} \mathrm{~L}^{-1} \mathrm{CV}$ at 910, 958, 1070, 1158, $1242,1287,1358,1384,1428,1524,1580$, and $1603 \mathrm{~cm}^{-1}$ are observed on the $\mathrm{Al}$ sheet. However, there are no obvious characteristic Raman peaks for $1 \times 10^{-7} \mathrm{~mol} \mathrm{~L}^{-1} \mathrm{CV}$ on $\mathrm{Al}$ (b) and $\mathrm{Al} / \mathrm{ZnO}$ (c), demonstrating that $\mathrm{Al}$ and $\mathrm{Al} / \mathrm{ZnO}$ are insensitive to $\mathrm{CV}$ at lower concentrations. In addition, as illustrated in Fig. 5A-d, only weak SERS signals of $1 \times 10^{-7} \mathrm{~mol} \mathrm{~L}^{-1} \mathrm{CV}$ are observed on $\mathrm{Al} / \mathrm{Ag}$, and also, the SERS response of $\mathrm{CV}$ is enhanced on the $\mathrm{ZnO} / \mathrm{Ag}$ substrate (Fig. 5A-e). Interestingly, the characteristic Raman peak of $\mathrm{CV}$ on the $\mathrm{Al} / \mathrm{ZnO} / \mathrm{Ag}$ substrate is significantly enhanced (Fig. 5A-f). As shown in Fig. 5B, the histogram of the SERS intensity of $\mathrm{CV}$ on $\mathrm{Al} / \mathrm{Ag}, \mathrm{ZnO} / \mathrm{Ag}$, and $\mathrm{Al} /$ $\mathrm{ZnO} / \mathrm{Ag}$ is given based on the characteristic Raman peak of $\mathrm{CV}$ at $1609 \mathrm{~cm}^{-1}$. Clearly, the SERS intensity of $\mathrm{CV}$ on the $\mathrm{Al} / \mathrm{ZnO} /$ $\mathrm{Ag}$ substrate is 5.6 and 9.75 times those on the $\mathrm{ZnO} / \mathrm{Ag}$ and $\mathrm{Al} /$ $\mathrm{Ag}$ substrates, respectively, demonstrating that there is strong synergistic effect among $\mathrm{Al}, \mathrm{ZnO}$, and $\mathrm{Ag}$. Also, the three dominant typical peaks of $\mathrm{CV}\left(1 \times 10^{-3} \mathrm{~mol} \mathrm{~L}^{-1}\right)$ at 1603 and $910 \mathrm{~cm}^{-1}$ on the Al sheet (Fig. 5A-a) shift to 1609 and $916 \mathrm{~cm}^{-1}$ on the $\mathrm{Al} / \mathrm{ZnO} / \mathrm{Ag}$ substrate (Fig. 5A-f), respectively. In addition, the two typical Raman bands of CV at 1358 and $1384 \mathrm{~cm}^{-1}$ belong to phenyl- $N$ stretching, which shift to 1363 and $1378 \mathrm{~cm}^{-1}$ on the $\mathrm{Al} / \mathrm{ZnO} / \mathrm{Ag}$ substrate, respectively. The above results indicate that the strong binding of $\mathrm{Ag}$ in $\mathrm{Al} / \mathrm{ZnO} / \mathrm{Ag}$ and " $\mathrm{N}$ " in CV takes place via the Ag-N bond.

In order to investigate the effect of the AgNPs' size on the activity of the substrate, the SERS response of CV $\left(1 \times 10^{-7} \mathrm{~mol} \mathrm{~L}^{-1}\right)$ on the $\mathrm{Al} / \mathrm{ZnO} / \mathrm{Ag}$ at different reduction times were collected. As shown in Fig. 5C and D, when the reduction time increases from 5 to $15 \mathrm{~min}$ (size of Ag: 44-99 $\mathrm{nm}$ ), the SERS intensity of CV gradually increased (a-c), and the SERS activity reaches the maximum when the reduction time is $15 \mathrm{~min}$ (size of Ag: $\sim 99 \mathrm{~nm}$ ). However, as the reduction time increases from 20 to $30 \mathrm{~min}$ (size of Ag: 100$110 \mathrm{~nm}$ ), the SERS intensity of $\mathrm{CV}$ on the $\mathrm{Al} / \mathrm{ZnO} / \mathrm{Ag}$ substrate is greatly decreased. On the basis of the above results, we can conclude that the SERS activity of the $\mathrm{Al} / \mathrm{ZnO} / \mathrm{Ag}$ substrate is closely related to the size of the AgNPs and the intergranular space, and the SERS activity of the $\mathrm{Al} / \mathrm{ZnO} / \mathrm{Ag}$ substrate is the highest when the size of $\mathrm{Ag}$ is $99 \mathrm{~nm}$, which generates strong LSPR. The difference in the activity of the SERS substrates could be attributed to the change in the amount and size of $\mathrm{Ag}$ in the substrate. In the initial stages of reduction (5 min), a small amount of AgNPs with small size $(\sim 44 \mathrm{~nm})$ appear on the $\mathrm{Al} / \mathrm{ZnO}$ nanosheets, which gradually enhance the SERS signal of $\mathrm{CV}$ on the $\mathrm{Al} / \mathrm{ZnO} / \mathrm{Ag}$ substrate. As the reduction time is in the range of 10-15 min, the size of AgNPs gradually increases (75-99 $\mathrm{nm}$ ), and more AgNPs are located on the surface and tip edges of the $\mathrm{ZnO}$ nanosheets, which significantly enhance the SERS activity of $\mathrm{CV}$ on the $\mathrm{Al} / \mathrm{ZnO} / \mathrm{Ag}$ substrate. However, as the reduction time continues to be prolonged, the size and amount of AgNPs increase, and the spacing between each AgNPs decrease sharply, leading to a great reduction in the SERS intensity of $\mathrm{CV}$ on the $\mathrm{Al} / \mathrm{ZnO} / \mathrm{Ag}$ substrate.

Fig. 6 shows the SERS spectra of $\mathrm{CV}$ on the $\mathrm{Al} / \mathrm{ZnO} / \mathrm{Ag}$ substrate at different concentrations. Clearly, the Raman response of $\mathrm{CV}$ is reduced gradually with the decrease in the $\mathrm{CV}$ concentration $(\mathrm{b}-\mathrm{h})$. When the concentration is $1 \times 10^{-13}$ mol L ${ }^{-1}$, some characteristic peaks of $\mathrm{CV}$ can still be observed, indicating that this $\mathrm{Al} / \mathrm{ZnO} / \mathrm{Ag}$ substrate possesses a high SERS detection sensitivity toward CV. The relationship of SERS intensity at a typical band of $1609 \mathrm{~cm}^{-1}$ and different concentrations of $\mathrm{CV}$ is illustrated in Fig. 6B. The results present a good linear relationship within the concentration range of $1 \times 10^{-7}-1 \times 10^{-13} \mathrm{~mol} \mathrm{~L}^{-1}$. Also, the detection limit of the $\mathrm{Al} / \mathrm{ZnO} / \mathrm{Ag}$ substrate for $\mathrm{CV}$ can reach $3.6 \times 10^{-14} \mathrm{~mol} \mathrm{~L}^{-1}$. It is indicated that the high SERS sensitivity is ascribed to the effective hot spots generated on the lamellar structure of $\mathrm{ZnO}$ nanosheets, which make AgNPs mainly distributed at the tip edges of the $\mathrm{ZnO}$ nanosheets, thus generating strong electromagnetic enhancement effect and enhancing the SERS signals.
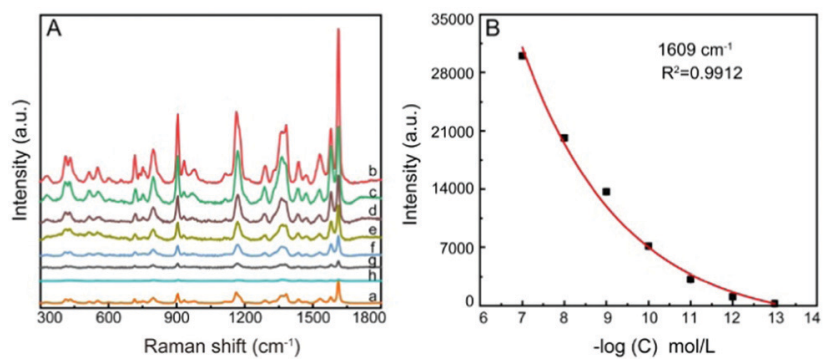

Fig. 6 (A) Raman spectra of $1 \times 10^{-3} \mathrm{~mol} \mathrm{~L}^{-1} \mathrm{CV}$ on Al (a) and SERS spectra of $\mathrm{CV}$ on $\mathrm{Al} / \mathrm{ZnO} / \mathrm{Ag}$ with different concentrations: (b) $1 \times 10^{-7} \mathrm{~mol} \mathrm{~L}^{-1}$, (c) $1 \times$ $10^{-8} \mathrm{~mol} \mathrm{~L}^{-1}$, (d) $1 \times 10^{-9} \mathrm{~mol} \mathrm{~L}^{-1}$, (e) $1 \times 10^{-10} \mathrm{~mol} \mathrm{~L}^{-1}$, (f) $1 \times 10^{-11} \mathrm{~mol} \mathrm{~L}^{-1}$, (g) $1 \times 10^{-12} \mathrm{~mol} \mathrm{~L}^{-1}$ and (h) $1 \times 10^{-13} \mathrm{~mol} \mathrm{~L}^{-1}$; (B) the relationship between the corresponding SERS intensity at $1609 \mathrm{~cm}^{-1}$ and different concentrations of CV. The error bar is the standard deviation of three samples. 
In addition, the analytical enhancement factor (AEF) of the substrate is estimated to be $2.45 \times 10^{8}$ for $\mathrm{Al} / \mathrm{ZnO} / \mathrm{Ag}$ (details in the ESI $\dagger$ ). The high AEF indicates that the $\mathrm{Al} / \mathrm{ZnO} / \mathrm{Ag}$ substrate can be used for the highly sensitive detection of environmental pollutants. As shown in Table S1, (ESI $\dagger$ ) it is found that the constructed $\mathrm{Al} / \mathrm{ZnO} / \mathrm{Ag}$ substrate exhibits a more sensitive SERS response toward $\mathrm{CV}$, and the content of $\mathrm{Ag}$ in this substrate is relatively small (only about $1.51 \mathrm{wt} \%$ ), indicating that the cost of the substrate is lower, which is competitive in practical application.

\subsection{Stability, uniformity, and repeatability of the substrate}

In actual analysis and detection, the stability, uniformity, and repeatability of the SERS substrate are also vital parameters. In order to study the stability of the substrate, the SERS spectra of $\mathrm{CV}$ on the same $\mathrm{Al} / \mathrm{ZnO} / \mathrm{Ag}$ substrate are collected at different weeks (Fig. 7A), and the corresponding SERS intensity at $1609 \mathrm{~cm}^{-1}$ is illustrated in Fig. 7B. Obviously, the SERS intensities are hardly changed at different storage times (1-6 weeks), indicating that the $\mathrm{Al} / \mathrm{ZnO} / \mathrm{Ag}$ substrate has excellent stability under air conditions due to the stacked lamellar structure of $\mathrm{ZnO}$, which can protect AgNPs from being oxidized in air. Also, the strong synergistic effect among $\mathrm{Al}, \mathrm{ZnO}$, and $\mathrm{Ag}$ could enhance the stability of $\mathrm{Al} / \mathrm{ZnO} / \mathrm{Ag}$ during long-term storage.

In addition, the Raman mapping of $\mathrm{CV}\left(1 \times 10^{-7} \mathrm{~mol} \mathrm{~L}^{-1}\right)$ on the $\mathrm{Al} / \mathrm{ZnO} / \mathrm{Ag}$ substrate was conducted with a selected area of $60 \times 60 \mu \mathrm{m}^{2}$. Obviously, it can be seen from Fig. 7C that the substrate has a high uniformity. Besides, the SERS intensity of $\mathrm{CV}$ at $1609 \mathrm{~cm}^{-1}$ with thirty-six randomly selected points is almost unchanged over the entire mapping area (Fig. 7D), and the relative standard deviation (RSD) is $7.41 \%$, indicating that this substrate is well distributed. It should be noted that the most important cause of this superior performance is the even
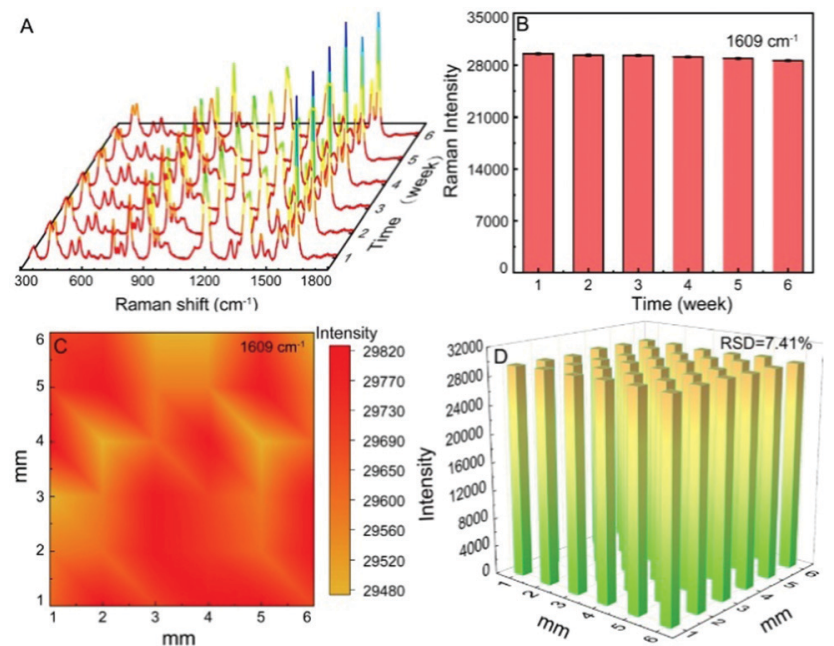

Fig. 7 (A) SERS spectra of CV $\left(1 \times 10^{-7} \mathrm{~mol} \mathrm{~L}^{-1}\right)$ on the $\mathrm{Al} / \mathrm{ZnO} / \mathrm{Ag}$ substrate measured within 6 weeks and (B) the corresponding column chart of SERS intensities at the band of $1609 \mathrm{~cm}^{-1}$; (C) the mapping of SERS intensity of $C V$ at $1609 \mathrm{~cm}^{-1}$ and (D) the corresponding cuboid for the SERS intensity in the mapping area $\left(6 \times 6 \mathrm{~mm}^{2}\right)$.

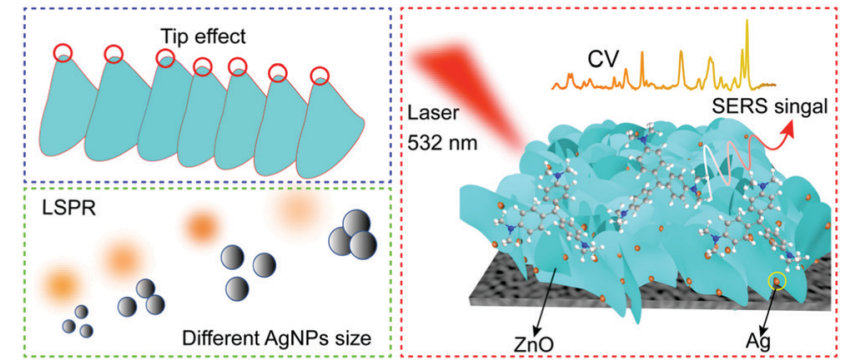

Scheme 2 SERS-enhanced mechanism diagram of the $\mathrm{Al} / \mathrm{ZnO} / \mathrm{Ag}$ substrate.

distribution of AgNPs on the lamellar structure of $\mathrm{Al} / \mathrm{ZnO}$, and a strong coupling effect between $\mathrm{ZnO}$ and AgNPs in the substrate.

Moreover, the repeatability of the $\mathrm{Al} / \mathrm{ZnO} / \mathrm{Ag}$ substrate is evaluated by collecting all the SERS spectra of CV after several cycles (Fig. S6A, ESI $\dagger$ ), and the SERS intensity of CV at the band of $1609 \mathrm{~cm}^{-1}$ was plotted (Fig. S6B, ESI $\dagger$ ). The results demonstrate that the SERS response of $\mathrm{CV}$ on the $\mathrm{Al} / \mathrm{ZnO} / \mathrm{Ag}$ substrate is almost unchanged after six cycles, and the relative SERS intensity is slightly decreased, indicating that the $\mathrm{Al} / \mathrm{ZnO} / \mathrm{Ag}$ substrate has good repeatability. Therefore, these results demonstrated that the $\mathrm{Al} / \mathrm{ZnO} / \mathrm{Ag}$ substrate can be used for highly sensitive SERS detection with excellent stability, uniformity, and reproducibility.

According to the above results, the highly sensitive SERS response of the $\mathrm{Al} / \mathrm{ZnO} / \mathrm{Ag}$ substrate was attributed to the electromagnetic mechanism and chemical mechanism (Scheme 2). Firstly, the $\mathrm{Al} / \mathrm{ZnO}$ surface provides dense lamellar porous structure with more tip areas, which generate abundant active sites for the growth of AgNPs. When appropriate amount and size of AgNPs are uniformly distributed on the tip regions of the $\mathrm{Al} / \mathrm{ZnO}$ lamellar structure, ${ }^{39}$ strong LSPR of AgNPs is generated, ${ }^{40}$ which corresponded to electromagnetic enhancement. Secondly, the outstanding SERS response of $\mathrm{CV}$ on the $\mathrm{Al} /$ $\mathrm{ZnO} / \mathrm{Ag}$ substrate is also attributed to the strong synergistic effect among $\mathrm{Al}, \mathrm{ZnO}$, and $\mathrm{Ag}$. Thirdly, $\mathrm{Al} / \mathrm{ZnO} / \mathrm{Ag}$ can absorb more $\mathrm{CV}$ molecules due to the strong binding of $\mathrm{Ag}$ in $\mathrm{Al} / \mathrm{ZnO} /$ $\mathrm{Ag}$ and " $\mathrm{N}$ " in CV via the Ag-N bond, which make CV molecules close to the hot spots generated by the highly active AgNPs; thus, the SERS signals are significantly enhanced. Meanwhile, the appropriate amount and size of AgNPs on the tip regions of $\mathrm{Al} / \mathrm{ZnO}$ possess high intensity of SPR, which can impel several "hot electrons" from ZnO to the CV molecules; hence, the excited-state charge transfer can easily be conducted, which is assigned to chemical enhancement. ${ }^{19}$ Thus, the dense lamellar porous structure of $\mathrm{Al} / \mathrm{ZnO}$ not only promotes AgNPs to produce high SERS enhancement effect but also facilitates the charge transfer process, and thus the SERS signals are significantly enhanced.

\subsection{Selectivity of the $\mathrm{Al} / \mathrm{ZnO} / \mathrm{Ag}$ substrate for the SERS detection of $\mathrm{CV}$ in spiked water samples}

Moreover, the selectivity of the $\mathrm{Al} / \mathrm{ZnO} / \mathrm{Ag}$ substrate for the detection of $\mathrm{CV}$ was evaluated. Fig. 8A displays the Raman 


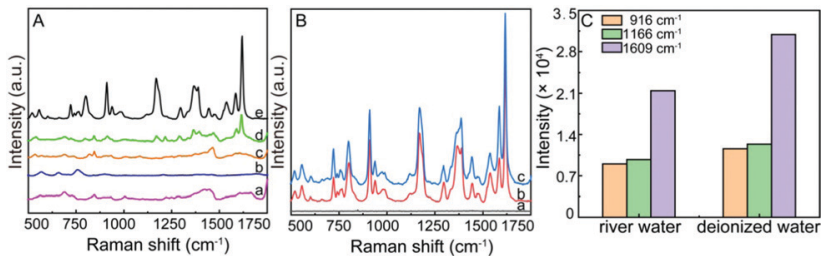

Fig. 8 (A) Raman response of 4-ATP (a), TA (b), MB (c), MG (d) and CV (e) on the $\mathrm{Al} / \mathrm{ZnO} / \mathrm{Ag}$ substrate at the same concentration of $1 \times$ $10^{-7} \mathrm{~mol} \mathrm{~L}^{-1}$; (B) SERS spectra of unspiked river water (a) and $1 \times 10^{-7}$

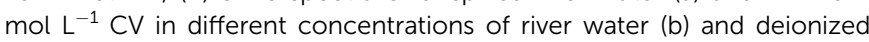
water (c) on the $\mathrm{Al} / \mathrm{ZnO} / \mathrm{Ag}$ substrate; (C) comparison of the peak intensity at 916,1166 and $1609 \mathrm{~cm}^{-1}$ of $1 \times 10^{-7} \mathrm{~mol} \mathrm{~L}^{-1} \mathrm{CV}$ in different solvents.

response of 4-ATP, TA, MB, MG, and CV at the same concentration of $1 \times 10^{-7} \mathrm{~mol} \mathrm{~L}^{-1}$ on the $\mathrm{Al} / \mathrm{ZnO} / \mathrm{Ag}$ substrate. The SERS spectrum of 4-ATP (a), TA (b), MB (c), and MG (d) is shown in Fig. 8A; clearly, only very weak peaks are observed for each molecule. Interestingly, the strong typical SERS peaks of CV are observed under the same conditions, which exhibit the highest SERS intensity on the $\mathrm{Al} / \mathrm{ZnO} /$ $\mathrm{Ag}$ substrate. The above results clearly demonstrated that the $\mathrm{Al} /$ $\mathrm{ZnO} / \mathrm{Ag}$ substrate shows high selectivity for the SERS detection of CV even at a low concentration. Moreover, in order to demonstrate the practicability of the $\mathrm{Al} / \mathrm{ZnO} / \mathrm{Ag}$ substrate for the SERS detection of $\mathrm{CV}, 1 \times 10^{-7} \mathrm{~mol} \mathrm{~L}^{-1} \mathrm{CV}$ was spiked in river water (Fig. 8B-b) and deionized water (Fig. 8B-c) for SERS analysis. Obviously, all the characteristic peaks of $\mathrm{CV}$ were clearly visible compared to that in unspiked river water (Fig. 8B-a). Importantly, $1 \times 10^{-7} \mathrm{~mol} \mathrm{~L}^{-1} \mathrm{CV}$ in the real river water still exhibits strong SERS response with the same concentration in deionized water on the $\mathrm{Al} / \mathrm{ZnO} / \mathrm{Ag}$ substrate (Fig. 8C). The results further confirm that the $\mathrm{Al} / \mathrm{ZnO} / \mathrm{Ag}$ substrate can be used for the highly sensitive SERS detection of CV with good selectivity in real-sample analysis.

\section{Conclusions}

In summary, Al sheet-induced stacked $\mathrm{ZnO}$ nanosheet structure was synthesized by a simple hydrothermal method (Al/ZnO). Subsequently, AgNPs were in situ decorated on the Al/ZnO surface, and a sensitive, cheap, and recyclable SERS substrate of $\mathrm{Al} / \mathrm{ZnO} / \mathrm{Ag}$ was prepared. The results indicated that there was a strong coupling effect between AgNPs and $\mathrm{ZnO}$ in $\mathrm{Al} / \mathrm{ZnO}$, and AgNPs were mainly distributed on the tip edges of the $\mathrm{ZnO}$ lamellar structure, and thus the effect of electromagnetic field is significantly enhanced. This substrate can be used for highly sensitive and selective SERS detection of $\mathrm{CV}$ molecules, and the limit of detection can reach $3.6 \times 10^{-14} \mathrm{~mol} \mathrm{~L}^{-1}$. In addition, the $\mathrm{Al} / \mathrm{ZnO} / \mathrm{Ag}$ substrate showed continuous stability, high uniformity, and good reproducibility. Therefore, the prepared $\mathrm{Al} / \mathrm{ZnO} / \mathrm{Ag}$ substrate with superior performance has potential application prospects in the SERS detection of environmental pollutants.

\section{Conflicts of interest}

There are no conflicts to declare.

\section{Acknowledgements}

This work was financially supported by Scientific Research Project of Shanghai Municipal Science and Technology Commission (No. 19090503700), the National Natural Science Foundation of China (No. 21771125, 21301118 and 21305092).

\section{References}

1 H. P. Fu, J. M. Chen, L. J. Chen, X. Zhu, Z. L. Chen, B. Qiu, Z. Y. Lin, L. H. Guo and G. N. Chen, Microchim. Acta, 2019, 186, 64-70.

2 Y. Z. Zhu, M. Tian, Y. Chen, Y. J. Yang, X. P. Liu and S. Y. Gao, Nano Energy, 2021, 83, 105824-105833.

3 Q. Q. Peng, N. Wang, Y. Zhu, J. Hu, H. Q. Peng, L. Li, B. Z. Zheng, J. Du and D. Xiao, J. Mater. Chem. C, 2019, 7, 10465-10470.

4 C. C. Li, Y. M. Huang, X. Y. Li, Y. R. Zhang, Q. L. Chen, Z. W. Ye, Z. Alqarni, S. E. J. Bell and Y. K. Xu, J. Mater. Chem. C, 2021, 9, 11517-11552.

5 Y. T. Long, H. Li, Z. J. Du, M. M. Geng and Z. R. Liu, J. Colloid Sci., 2021, 581, 698-708.

6 A. D. Chowdhury, F. Nasrin, R. Gangopadhyay, A. B. Ganganboina, K. Takemura, I. Kozaki, H. Honda, T. Hara, F. Abe, S. Park, T. Suzuki and E. Y. Park, Biosens. Bioelectron., 2020, 170, 112657-112666.

7 S. Yang, X. Dai, B. B. Stogin and T. S. Wong, Proc. Natl. Acad. Sci. U. S. A., 2016, 113, 268-273.

8 T. Zhang, Y. Sun, L. Hang, H. Li, G. Liu, X. Zhang, X. Lyu, W. Cai and Y. Li, ACS Appl. Mater. Interfaces, 2018, 10, 9792-9801.

9 Z. Y. Cao, P. He, T. Huang, S. W. Yang, S. C. Han, X. Y. Wang and G. Q. Ding, Chem. Mater., 2020, 32, 3813-3822.

10 K. G. Stamplecoskie, J. C. Scaiano, V. S. Tiwari and H. Anis, J. Phys. Chem. C, 2011, 115, 1403-1409.

11 V. Consonni, J. Briscoe, E. Karber, X. Li and T. Cossuet, Nanotechnology, 2019, 30, 362001-362012.

12 L. Roza, V. Fauzia and M. Y. Abd Rahman, Appl. Surf. Sci., 2019, 15, 117-124.

13 T. Dutta, D. Bagchi, A. Bera, S. Das, T. Adhikari and S. K. Pal, ACS Sustainable Chem. Eng., 2019, 7, 10920-10932.

14 E. Proniewicz, A. Tata, M. Starowicz, A. Szkudlarek, J. Pacek, M. Molenda and P. Kustrowski, Spectrochim. Acta, 2019, 215, 24-33.

15 C. Liu, Q. Song, J. Chen, X. Li, J. Cai, Z. Lu, W. Li, N. X. Fang and S. P. Feng, Adv. Mater. Interfaces, 2019, 6, 1900534-1900545.

16 Y. Quan, J. Yao, S. Yang, L. Chen, J. Li, Y. Liu, J. Lang, H. Shen, Y. Wang, Y. Wang, J. Yang and M. Gao, Microchim. Acta, 2019, 186, 593-601.

17 X. L. Zheng, H. L. Guo, Y. Xu, J. L. Zhang and L. Z. Wang, J. Mater. Chem. C, 2020, 8, 13836-13842.

18 L. Zhou, H. Zhang, H. Bao, G. Liu, Y. Li and W. Cai, J. Phys. Chem. C, 2018, 122, 8628-8636.

19 J. Zhou, J. Zhang, H. Yang, Z. Wang, J. A. Shi, W. Zhou, N. Jiang, G. Xian, Q. Qi, Y. Weng, C. Shen, Z. Cheng and S. He, Nanoscale, 2019, 11, 11782-11788. 
20 S. J. Li, N. N. Zhang, N. M. Zhang, D. D. Lin, X. F. Hu and X. J. Yang, Sens. Actuators, B, 2020, 321, 128519-128528.

21 Q. Sun, Q. Y. Zhang, N. Zhou, L. Y. Zhang and Z. Yi, Appl. Surf. Sci., 2020, 526, 146565-146574.

22 X. Wang, W. Shi, Z. Jin, W. Huang, J. Lin, G. Ma, S. Li and L. Guo, Angew. Chem., Int. Ed., 2017, 56, 9851-9855.

23 J. Lin, J. Yu, O. U. Akakuru, X. T. Wang, B. Yuan, T. X. Chen, L. Guo and A. G. Wu, Chem. Sci., 2020, 11, 9414-9420.

24 X. He, Y. Liu, Y. Liu, S. Cui, W. Liu and Z. B. Li, CrystEngComm, 2020, 22, 776-785.

25 Y. Wang, X. F. Yu, Y. H. Chang, C. L. Gao, J. Chen, X. L. Zhang and J. H. Zhan, Microchim. Acta, 2019, 186, 458-466.

26 L. Q. Kong, Y. J. Ji, Z. Z. Dang, J. Q. Yan, P. Li, Y. Y. Li and S. Z. Liu, Adv. Funct. Mater., 2018, 28, 1800668-1800677.

27 Y. N. Xia, P. D. Yang, Y. G. Sun, Y. Y. Wu, B. Mayers, B. Gates, Y. D. Yin, F. Kim and H. Q. Yan, Adv. Mater., 2003, 15, 353-389.

28 Y. Cheng, W. Z. Wang, L. Z. Yao, J. Wang, H. S. Han, T. Y. Zhu, Y. J. Liang, J. L. Fu and Y. N. Wang, Colloids Surf., A, 2020, 607, 125507-125516.

29 Z. M. Zhang, J. Hu, Y. Y. Wang, R. C. Shi, Y. W. Ma, H. L. Huang, H. Wang, J. X. Wei and Q. J. Yu, Corros. Sci., 2021, 184, 109393-109404.

30 F. Lu, J. Wang, Z. Chang and J. Zeng, Mater. Des., 2019, 14, 108069-108081.
31 S. Shao, X. Chen, Y. Chen, L. Zhang, H. W. Kim and S. S. Kim, ACS Appl. Nano Mater., 2020, 3, 5220-5230.

32 Q. C. Li, D. Chen, J. M. Miao, S. J. Lin, Z. X. Yu, D. X. Cui, Z. Yang and X. P. Chen, Sens. Actuators, B, 2021, 326, 128952-128961.

33 H. H. Yu, Q. L. Liao, Z. Kang, Z. Y. Wang, B. S. Liu, X. K. Zhang, J. L. Du, Y. Ou, M. Y. Hong, J. K. Xiao, Z. Zhang and Y. Zhang, Small, 2020, 26, 2005520-2005529.

34 B. P. Zhang, D. J. Yang, X. Q. Qiu, Y. Qian, H. Wang, C. H. Yi and D. Q. Zhang, Carbon, 2020, 162, 256-266.

35 C. D. Wang, X. H. Xu, G. Y. Qiu, W. C. Ye, Y. M. Li, R. A. Harris and C. Y. Jiang, Anal. Chem., 2021, 93, 3403-3410.

36 J. M. Chen, Z. R. Shen, S. M. L. K. Shen, R. F. Wu, X. F. Jiang, T. Fan and J. Y. Chen, J. Mater. Chem. A, 2018, 6, 19631-19642.

37 H. Mou, C. Song, Y. Zhou, B. Zhang and D. Wang, Appl. Catal., B, 2018, 221, 565-573.

38 A. A. Vinotha, D. Tushar, N. Chandrasekaran and M. Amitava, Anal. Chim. Acta, 2021, 1142, 73-83.

39 L. Zhang, X. D. Li, Y. Y. Jin, Y. L. Zhang, X. M. Liu, Y. L. Chang, L. J. Xu, H. Y. Zhao, L. P. Tu, D. Wang, X. G. Kong and B. Xue, Appl. Surf. Sci., 2019, 493, 423-430.

40 T. Wang, Y. Huang, Z. Liu and N. R. Barveen, J. Alloys Compd., 2021, 864, 158120-158130. 